\title{
PENGARUH RASIO LEVERAGE, PANGSA PASAR, DAN INTENSITAS MODAL TERHADAP PROFITABILITAS PADA PERUSAHAAN MAKANAN DAN MINUMAN YANG TERDAFTAR DI BEI TAHUN 2014-2016
}

\author{
${ }^{1}$ Nurwani, ${ }^{2}$ Tika Mayunita \\ ${ }^{1,2}$ Universitas Muhammadiyah Sumatera Utara \\ Email ; ${ }^{\prime}$ nurwani@umsu.ac.id \\ ²tikamayunita@yahoo.com
}

\begin{abstract}
ABSTRAK
Profitabilitas mempunyai arti penting dalam usaha mempertahankan kelangsungan hidupnya dalam jangka panjang. Karena profitabilitas menunjukkan perusahaan tersebut mempuyai prospek yang baik dimasa yang akan datang. Dengan demikian setiap perusahaan akan selalu berusaha meningkatkan profitabilitasnya, karena semakin tinggi tingkat profitabilitasnya suatu perusahaan maka kelangsungan perusahaan tersebut akan lebih terjamin. Penelitian ini bertujuan untuk mengetahui dan menganalisis pengaruh rasio leverage, pangsa pasar, dan intensitas modal terhadap profitabilitas pada perusahaan makanan dan minuman yang terdaftar di BEI pada tahun 2014-2016 baik secara parsial maupun secara simultan. Teknik pengumpulan datanya studi dokumentasi. Teknik analisis yang digunakan dalam penelitian ini adalah analisis regresi linear berganda untuk menguji hipotesis yang terlebih dahulu harus dilakukan uji asumsi klasik dengan program SPSS. Adapun hasil dari penelitian ini yang pertama adalah leverage berpengaruh negatif signifikan terhadap profitabilitas. kedua pangsa pasar berpengaruh positif signifikan terhadap profitabilitas. ketiga intensitas modal berpengaruh positif signifikan terhadap profitabilitas. Keempat leverage, pangsa pasar, dan intensitas modal berpengaruh secara simultan terhadap profitabilitas pada perusahaan makanan dan minuman yang terdaftar di BEI tahun 2014-2016.
\end{abstract}

Kata kunci: Leverage, Pangsa Pasar, Intensitas Modal, Profitabilitas

\begin{abstract}
Profitability has an important meaning in the effort to maintain its long-term survival. Because profitability shows that the company has good prospects in the future. Thus each company will always try to increase its profitability, because the higher the level of profitability of a company, the continuity of the company will be more guaranteed. This study aims to determine and analyze the effect of leverage ratio, market share, and capital intensity on profitability in food and beverage companies listed on the Stock Exchange in 2014-2016, both partially and simultaneously. Data collection techniques are documentation studies. The analytical technique used in this study is multiple linear regression analysis to test the hypothesis that must first be tested for classic assumptions with the SPSS program. The results of this study the first is leverage has a significant negative effect on profitability. The second market shares has a significant positive effect on profitability. The third capital intensity has a significant positive effect on profitability. The fourth leverage, market share, and capital intensity simultaneously affect profitability in food and beverage companies listed on the Stock Exchange in 2014-2016.
\end{abstract}

Keywords: leverage, market share, capital intensity, profitability 


\section{PENDAHULUAN}

\section{A.Latar Belakang Masalah}

Perusahaan makanan dan minuman merupakan salah satu kategori sektor industri di Bursa Efek Indonesia (BEI) yang mempunyai peluang untuk tumbuh dan berkembang. Kondisi ini membuat persaingan semakin ketat sehingga para manajer perusahaan berlombalomba mencari investor untuk menginvestasikan dananya di perusahaan makanan dan minuman tersebut.

Kinerja keuangan sebagai refleksi gambaran dari pencapaian keberhasilan perusahaan dapat diartikan sebagai hasil yang telah dicapai atas berbagai aktivitas yang telah dilakukan. Untuk mengukur kinerja keuangan menggunakan rasio profitabilitas. Profitabilitas mempunyai arti penting dalam usaha mempertahankan kelangsungan hidupnya karena profitabilitas menunjukkan perusahaan tersebut mempunyai prospek yang baik di masa yang akan datang.

Rasio leverage merupakan keputusan keuangan yang penting karena mempengaruhi kinerja dan nilai perusahaan. Rasio leverage menunjukkan proposi atas penggunaan hutang untuk membiayai investasinya, sehingga dengan mengetahui rasio leverage, investor dapat mengetahui keseimbangan antara risiko dan tingkat pengembalian investasinya
Indikator posisi perusahaan dalam persaingan industri dapat diukur dari pangsa pasar ( market share). Semakin tinggi pangsa pasar mencerminkan kekuatan perusahaan dalam persaingan pasar. Semakin tinggi pangsa pasar atau semakin tinggi penjualan relatif perusahaan dalam industri berarti semakin tinggi penerimaan perusahaan yang merupakan komponen penting dalam perhitungan laba.

Intensitas modal merupakan salah satu bentuk keputusan keuangan. Keputusan tersebut ditetapkan oleh manajemen perusahaan dimaksudkan untuk meningkatkan profitabilitas perusahaan. Dalam persaingan industri yang perlu diperhatikan adalah tingkat hambatan keluar masuk industri ( barrier to entry ). Hal ini diukur dengan menggunakan rasio intensitas modal. Semakin tinggi rasio ini menjadi semakin tidak menarik bagi pendatang baru untuk masuk industri karena dibutuhkan lebih banyak aset untuk menghasilkan setiap unit penjualan.

Pada penelitian Fitri (2008) yang berjudul pengaruh pangsa pasar, rasio leverage dan rasio intensitas modal terhadap profitabilitas pada perusahaan Real Estate dan property terdaftar di bursa efek indonesia. Dengan hasil penelitian bahwa pangsa pasar mempunyai pengaruh yang signifikan terhadap ROA perusahaan sedangkan variabel rasio Leverage dan rasio intensitas modal tidak 
mempunyai pengaruh yang signifikan terhadap ROA perusahaan.

Pada penelitian Winarno, Lina Nur Hidayati dkk (2015) yang berjudul Faktor-faktor yang mempengaruhi profitabilitas perusahaan manufaktur yang Listed di bursa efek indonesia. Dengan hasil penelitian pangsa pasar, leverage, dan pertumbuhan penjualan secara parsial tidak memiliki pengaruh yang signifikan terhadap profitabilitas, sedangkan intensitas modal dan total asset secara parsial memiliki pengaruh positif dan signifikan terhadap profitabilitas . hal ini mengindikasikan bahwa profitabilitas perusahaan lebih banyak ditentukan intensitas modal dan total asset dibandingkan pangsa pasar,leverage, dan pertumbuhan penjualan.

Pada penelitian Purwanti (2010) yang berjudul Pengaruh pangsa pasar, rasio leverage, intensitas modal terhadap profitabilitas koperasi simpan pinjam di sala tiga. Dengan hasil penelitian menunjukkan bahwa pangsa pasar, rasio leverage dan intensitas modal secara bersama berpengaruh signifikan terhadap return on asset dan return on equity atau profitabilitas namun, demikian secara individu rasio leverge, intensitas modal tidak berpengaruh signifikan terhadap return on asset dan return on equity atau profitabilitas.

Berdasarkan uraian di atas
maka peneliti tertarik untuk
melakukan penelitian mengenai

pengaruh rasio leverage, pangsa pasar, dan intensitas modal terhadap profitabilitas pada perusahaan makanan dan minuman yang terdaftar di BEI tahun 2014-2016.

Adapun rumusan masalah dalam penelitian ini adalah

1. Apakah rasio leverage berpengaruh terhadap profitabilitas pada perusahaan makanan dan minuman yang terdaftar di BEI tahun 2014-2016?

2. Apakah pangsa pasar berpengaruh terhadap profitabilitas pada perusahaan makanan dan minuman yang terdaftar di BEI tahun 20142016?

3. Apakah intensitas modal berpengaruh terhadap profitabilitas pada perusahaan makanan dan minuman yang terdaftar di BEI tahun 2014-2016?

4. Apakah rasio leverage, pangsa pasar, intensitas modal berpengaruh terhadap profitabilitas pada perusahaan makanan dan minuman yang terdaftar di BEI tahun 2014-2016 secara simultan?

\section{B. Leverage}

Leverage merupakan rasio yang digunakan untuk mengukur asset yang dimiliki perusahaan berasal dari hutang atau modal. Rasio leverage diukur dengan Debt to Asset Ratio (DAR)

Debt to asset Ratio $=\frac{\text { Total Debt }}{\text { Total asset }}$ 


\section{Pangsa Pasar}

Pangsa pasar merupakan perubahan yang terjadi pada total penjualan perusahaan.

\section{Pangsa Pasar $=$ \\ $\frac{\text { Penjualanbersih }}{\text { Total penjualanindustri }}$}

\section{Intensitas Modal}

Intensitas modal merupakan rasio yang digunakan untuk mengukur perbandingan antara total penjualan dengan total aset.

Intensitas modal $=\frac{\text { penjualan }}{\text { total aktiva }}$

\section{E. Profitabilitas}

Profitabilitas merupakan rasio yang digunakan untuk mengukur kemampuan perusahaan dalam menghasilkan laba dari asset, modal dan penjualan yang dimiliki oleh perusahaan. Rasio profitabilitas diukur dengan return on asset (ROA).

\section{Return On Asset $($ ROA $)=$

$\frac{\text { Laba Setelah pajak }}{\text { Total Aset }}$

Adapun hipotesis dalam penelitian ini adalah sebagai berikut :

1. Rasio leverage berpengaruh terhadap profitabilitas pada perusahaan makanan dan minuman yang terdaftar di BEI.

2. Pangsa pasar berpengaruh terhadap profitabilitas pada perusahaan makanan dan minuman yang terdaftar di BEI.
3. Intensitas modal berpengaruh terhadap profitabilitas pada perusahaan makanan dan minuman yang terdaftar di BEI.

4. Rasio leverage, pangsa pasar dan intensitas modal berpengaruh terhadap profitabilitas pada perusahaan makanan dan minuman yang terdaftar di BEI secara simultan.

\section{METODOLOGI PENELITIAN}

Penelitian menggunakan pendekatan asosiatif yang bertujuan untuk mengetahui pengaruh leverage, pangsa pasar dan intensitas modal terhadap profitabilitas pada perusahaan makanan dan minuman yang terdaftar di BEI.

Teknik Pengumpulan data yang digunakan adalah studi dokumentasi.

Metode analisis data yang digunakan untuk menguji hipotesis adalah regresi linier berganda yang terlebih dahulu harus dilakukan uji asumsi klasik. Teknik analisis data menggunakan program Statistical Package For Social Science (SPSS). Adapun persamaan regresi linier berganda sebagai berikut:

$$
\mathrm{Y}=\mathrm{a}+\mathrm{b}_{1} \mathrm{x}_{1}+\mathrm{b}_{2} \mathrm{X}_{2}+\mathrm{b}_{3} \mathrm{X}_{3}+\mathrm{e}
$$

Keterangan:

$$
\begin{array}{lll}
\mathrm{Y} & =\text { Profitabilitas } \\
\mathrm{a} & =\text { Konstanta persamaan } \\
& \text { regresi } \\
\mathrm{b}_{1}, \mathrm{~b}_{2}, & \mathrm{~b}_{3}, & =\text { Koefisien regresi } \\
\mathrm{x}_{1} & =\text { Leverage } \\
\mathrm{x}_{2} & =\text { Pangsa pasar }
\end{array}
$$


Tema : "Strategi Membangun Penelitian Terapan yang Bersinergi dengan Dunia Industri, Pertanian dan Pendidikan dalam Meningkatkan Daya Saing Global"
$\mathrm{x}_{3}$
$=$ Intensitas modal
e $\quad=$ Eror

\section{HASIL DAN PEMBAHASAN}

\section{B. Uji Multikolinearitas}

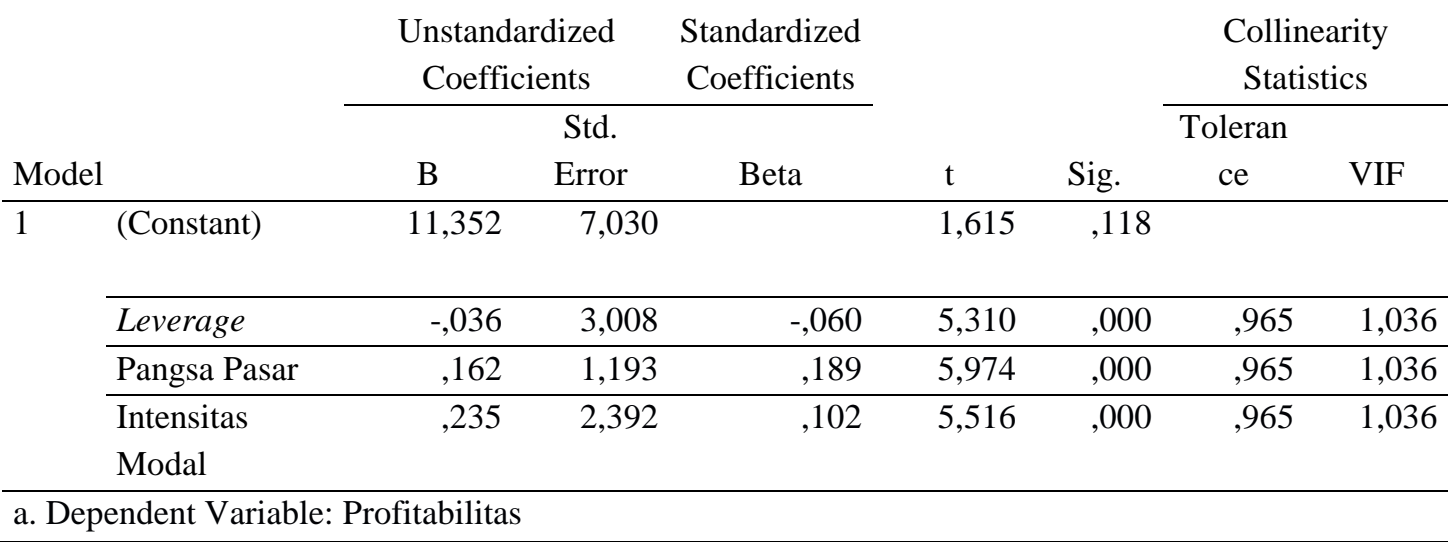

Tabel 2. Uji Multikolinearitas

Berdasarkan tabel 2 dapat dilihat bahwa tidak terjadi multikolinieritas karena nilai VIF masing-masing variabel lebih kecil dari 10 dan nilai tolerancenya lebih besar dari 0.10

\section{a. Uji Heteroskedastisitas}

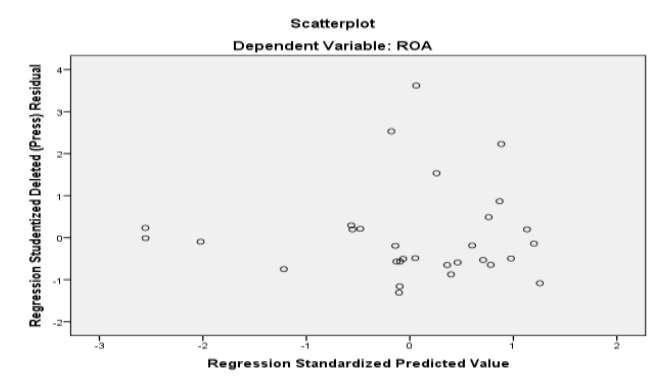

\section{Gambar 1. Uji Heteroskedastisitas}

Dari gambar scater plot diatas dapat dilihat bahwa titik menyebar keatas dan dibawah sumbu 0 pada sumbu Y dan ini menunjukkan bahwa data penelitian ini tidak terjadi gejala heteroskedasitas.

\section{b. Uji Autokorelasi}

2. Tabel 3. Uji Autokorelasi

\begin{tabular}{lrrrr}
\hline $\begin{array}{l}\text { Mode } \\
1\end{array}$ & R & R Square & Adjust R Square & Durbin-Watson \\
& & & & \\
\hline 1 & $.731(\mathrm{a})$ & .653 & .559 & 1,711 \\
\hline
\end{tabular}


Berdasarkan tabel 3 ada autokorelasi, dari pengamatan ini memperlihatkan nilai statistik D-W dapat disimpulkan bahwa tidak terjadi sebesar 1,311. Nilai ini terletak di autokorelasi dalam penelitian ini.

kriteria $1,65<1,711<2,35$ maka tidak

Hasil Analisis Regresi Linier Berganda

Tabel 4. Hasil Analisis Regresi Linier Berganda

\begin{tabular}{|c|c|c|c|c|c|}
\hline \multirow[b]{2}{*}{ Model } & \multicolumn{2}{|c|}{$\begin{array}{l}\text { Unstandardized } \\
\text { Coefficients }\end{array}$} & \multirow{2}{*}{$\begin{array}{c}\text { Standardized } \\
\text { Coefficients }\end{array}$} & \multirow[b]{2}{*}{$\mathrm{t}$} & \multirow[b]{2}{*}{ Sig. } \\
\hline & $\mathrm{B}$ & Std. Error & & & \\
\hline (Constant) & 11,352 & 7,030 & & 1,615 & , 118 \\
\hline
\end{tabular}

\begin{tabular}{lccccc}
\hline Leverage &,- 036 & 3,008 &,- 060 & 5,310 &, 000 \\
\hline Pangsa Pasar &, 162 & 1,193 &, 189 & 5,974 &, 000 \\
\hline $\begin{array}{l}\text { Intensitas } \\
\text { Modal }\end{array}$ &, 235 & 2,392 &, 102 & 5,516 &, 000 \\
\hline
\end{tabular}

Berdasarkan tabel 4 diatas akan didapat persamaan regresi sederhana model regresi sebagai berikut :

$$
\mathrm{Y}=\mathrm{a}+\mathrm{b}_{1} \mathrm{x}_{1}+\mathrm{b}_{2} \mathrm{x}_{2}+\mathrm{b}_{3} \mathrm{x}_{3}+\mathrm{e}
$$

Profitabilitas $=11,352-0.036$

leverage +0.162 pangsa pasar $+0,235$ intensitas modal

Berdasarkan persamaan regresi diatas dapat dijelaskan sebagai berikut:

1. Semua variabel independen yang terdiri dari leverage, pangsa pasar, dan intensitas modal diasumsikan bernilai nol maka nilai dari profitabilitas adalah 11,352 .

2. Hasil koefisien regresi leverage adalah -0,036 menunjukkan bahwa apabila variabel leverage meningkatkan 1 satuan maka akan menurunkan profitabilitas sebesar 0,036 satuan dengan asumsi variabel independen lainnya bernilai nol.

3. Hasil koefesien regresi pangsa pasar 0,162 menunjukkan bahwa apabila variabel pangsa pasar meningkat 1 satuan maka akan menurunkan profitabilitas sebesar 0,162 satuan dengan asumsi variabel independen lainnya bernilai nol.

4. Hasil koefesien regresi intensitas modal 0,235 menunjukkan bahwa apabila variabel intensitas modal meningkat 1 satuan maka akan 
menurunkan profitabilitas sebesar 0,235 satuan dengan asumsi variabel independen lainnya bernilai nol.

\section{Hasil Pengujian Hipotesis}

\section{Uji t (t-tes) Tabel 5. Uji t}

\begin{tabular}{|c|c|c|c|c|c|c|}
\hline \multirow{2}{*}{\multicolumn{2}{|c|}{ Model }} & \multicolumn{2}{|c|}{$\begin{array}{c}\text { Unstandardized } \\
\text { Coefficients }\end{array}$} & \multirow{2}{*}{$\begin{array}{c}\text { Standardized } \\
\text { Coefficients } \\
\text { Beta }\end{array}$} & \multirow[b]{2}{*}{$\mathrm{t}$} & \multirow[b]{2}{*}{ Sig. } \\
\hline & & B & Std. Error & & & \\
\hline \multirow[t]{5}{*}{1} & (Constant) & 11,352 & 7,030 & & 1,615 & ,118 \\
\hline & Leverage &,- 036 & 3,008 &,- 060 & 5,310 & ,000 \\
\hline & Pangsa Pasar & 162 & 1,193 & ,189 & 5,974 & $\overline{0}, 000$ \\
\hline & Intensitas & ,235 & 2,392 & ,102 & 5,516 & 900 \\
\hline & Modal & & & & & \\
\hline
\end{tabular}

Berdasarkan tabel 5 hasil penelitian ini adalah sebagai berikut:

1. Rasio leverage berpengaruh negatif signifikan terhadap profitabilitas dengan nilai sebesar 0,000 (Sig $0,000<\alpha 0.05$ ). Hal ini berarti Hipotesis pertama rasio leverage berpengaruh terhadap profitabilitas.

2. Pangsa pasar berpengaruh positif signifikan terhadap profitabilitas dengan nilai sebesar 0,000 (Sig

Uji F (F-tes) Tabel 6. Uji F

\begin{tabular}{llrrrrr}
\hline \multicolumn{1}{l}{ Model } & Sum of Squares & Df & Square & F & Sig. \\
\hline 1 & Regression & 130,076 & 3 & 43,359 & 25,488 &, $000^{\mathrm{b}}$ \\
\cline { 2 - 6 } & & & & & \\
\cline { 2 - 6 } & Residual & 2307,963 & 26 & 88,768 & & \\
\hline & Total & 2438,038 & 29 & & & \\
\hline
\end{tabular}

a. Dependent Variable: Profitabilitas

b. Predictors: (Constant), Intensitas Modal, Pangsa Pasar, Leverage $0,000<\alpha 0,05)$. Hal ini berarti Hipotesis pertama pangsa pasar berpengaruh terhadap profitabilitas.

3. Intensitas modal berpengaruh positif signifikan terhadap profitabilitas dengan nilai sebesar 0,000 (Sig $0,000<\alpha 0,05$ ). Hal ini berarti Hipotesis pertama intensitas modal berpengaruh signifikan terhadap profitabilitas. 
Berdasarkan tabel 6 hasil penelitian ini adalah sebesar 0,000 dengan nilai signifikan rasio leverage hal ini berarti bahwa hipotesis keempat diterima yang artinya rasio Uji Koefisien Determinasi $\left(\mathbf{R}^{2}\right)$

Tabel 7. Uji Koefisien Determinasi

\begin{tabular}{lllll}
\hline Model & R & R Square & Adjust R Square & Durbin-Watson
\end{tabular}

leverage, pangsa pasar, intensitas modal berpengaruh terhadap profitabilitas secara simultan.
Berdasarkan tabel 7 semakin tinggi rasio ini berarti memperlihatkan bahwa nilai Adjusted $R$ Square sebesar 0.559 yang berarti bahwa persentase pengaruh variabel independen terhadap profitabilitas sebesar $55.9 \%$ sedangkan sisanya $44.1 \%$ dipengaruhi atau dijelaskan oleh variabel lain yang tidak dimasukkan dalam model penelitian ini.

\section{PEMBAHASAN}

\section{Pengaruh Leverage Terhadap Profitabilitas}

Berdasarkan hasil penelitian ini diperoleh nilai signifikansi Leverage berdasarkan uji $\mathrm{t}$ diperoleh sebesar 0.000 (Sig $0.000<\alpha 0.05$ ). Hal ini berarti bahwa rasio leverage berpengaruh negatif signifikan terhadap profitabilitas.

Rasio leverage yang menggambarkan seberapa jauh perusahaan dibiayai oleh hutang atau pihak luar. Rasio hutang sebagai rasiorasio yang dimaksudkan untuk mengukur sampai berapa jauh aktiva perusahaan dibiayai dengan hutang, semakin besar jumlah modal pinjaman yang digunakan untuk investasi pada aktiva guna menghasilkan profitabilitas bagi perusahaan.

\section{Pengaruh Pangsa Pasar Terhadap Profitabilitas}

Berdasarkan hasil penelitian ini diperoleh nilai signifikansi pangsa pasar berdasarkan uji $\mathrm{t}$ diperoleh sebesar 0.000 (Sig $0.000<\alpha$ 0.05). Hal ini berarti bahwa pangsa pasar berpengaruh positif signifikan terhadap profitabilitas.

Weston dan Brigham (201, hal. 80) menyatakan pangsa pasar menimbulkan konsekuensi pada peningkatan investasi atas aktiva perusahaan dan akhirnya pangsa pasar yang mengalami meningkatan dapat meningkatkan tingkat pengembalian atas asset perusahaan/ Return on asset (ROA).

$$
\text { Pangsa pasar dalam }
$$
manajemen keuangan diukur berdasar perubahan penjualan, bahkan secara keuangan dapat dihitung berapa 
pertumbuhan yang seharusnya (Sustainable Growth Rate) dengan melihat keselarasan keputusan investasi dan pembiayaan. Pangsa pasar yang besar akan meningkatkan penjualan, meningkatnya penjualan akan berpengaruh terhadap profitabiitas perusahaan.

\section{Pengaruh Intensitas Moda Terhadap Profitabilitas}

Berdasarkan hasil penelitian ini diperoleh nilai signifikansi intensitas modal berdasarkan uji $\mathrm{t}$ diperoleh sebesar 0.000 (Sig $0.000<\alpha 0.05$ ). Hal ini berarti bahwa intensitas modal berpengaruh positif signifikan terhadap profitabilitas.

Intensitas modal merupakan salah satu bentuk keputusan keuangan. Keputusan tersebut ditetapkan oleh manajemen perusahaan dimaksudkan untuk meningkatkan profitabilitas perusahaan. Penggunaan intensitas

\section{DAFTAR PUSTAKA}

Fitri, Y. (2008). Pengaruh pangsa pasar, Rasio Leverage, dan Rasio Intensitas Modal terhadap Profitabilitas pada perusahaan Real Estate dan property Yang terdaftar di BEI Jakarta. Jurnal Ichsan Gorontalo, 3(1). modal didefenisikan sebagai rasio antar fixed asset seperti peralatan. Mesin dan berbagai properti terhadap asset total. Rasio ini menggambarkan seberapa besar asset perusahaan diinvestasikan dalam bentuk peralatan untuk meningkatkan profitabilitas perusahaan.

\section{KESIMPULAN}

Kesimpulan dalam penelitian ini sebagai berikut :

1. Rasio leverage berpengaruh negatif signifikan terhadap profitabilitas.

2. Pangsa pasar berpengaruh positif signifikan terhadap profitabilitas .

3. Intensitas modal berpengaruh positif signifikan terhadap profitbilitas.

4. Rasio leverage, pangsa pasar, dan intensitas modal berpengaruh signifikan terhadap profitbilitas.

Purwati, E. (2010). Pengaruh pangsa pasar, Rasio Leverage, Intensitas Modal terhadap Profitabilitas Koperasi simpan pinjam di salatiga. Jurnal Ekonomi Ama Salatiga Ilmiah Among Makarti, 3(5). 
Tema : "Strategi Membangun Penelitian Terapan yang Bersinergi dengan Dunia Industri, Pertanian dan Pendidikan dalam Meningkatkan Daya Saing Global"

06 November 2018, Kisaran

Ghozali, I. (2016). Aplikasi Analisis Multivariat dengan Program SPSS. Semarang : Badan Penerbit Universitas Dipenegoro

Sugiyono. (2014). Metode Penelitian

Bisnis. Bandung : CV. Alfabeta
Winarno, Lina Nur Hidayanti ddk. (2015). Faktor-faktor yang mempengaruhi profitabilitas perusahaan Manufaktur yang Listed di BEI. Jurnal Ekonomi, 11 (2) 